\title{
Migrants and the transformation of local neighbourhoods: A study of the socioeconomic transformation of Lidcombe, Australia
}

A major contributor to negative attitudes towards migrants is that they exert pressure on the facilities of the host communities without making any (substantial) contribution to the host economy and society. This negative sentiment is particularly acute in cities, where pressure on amenities is concentrated and more visible. In turn, migrant neighbourhoods are particularly despised. Migration experiences in the Rookwood Cemetery area of Sydney, Australia, widely regarded as the "largest necropolis in the southern hemisphere", however, challenge this stereotypical view. This migrant neighbourhood is the site of vibrant and diverse migration and migrant (especially Korean) activities never before seen in the history of the area, which is now called Lidcombe. Drawing on multiple sources of evidence, including archival research at local libraries, discussion with long-time residents of the neighbourhood and visual ethnography (analysed from the historical-structural perspective in migration studies), this study offers a history of Lidcombe and appraises its twenty-first-century migration experiences. By doing so, it highlights the demographic, social and economic changes to emphasise the contribution of migrants to the regeneration of a "dead city" and also to contest inherited stereotypes of migrants that often lead to racial scapegoating and misrepresentation as "parasites", "criminals" and a "drain" on the host economy. Overall, this case study suggests that migrants can and often do transform the spaces they occupy in ways that make a positive and lasting contribution to the host economy and society more generally. This is an important lesson for European countries facing the "migrant crisis" to consider, as it also is for politicians around the world seeking to wall out migrants to protect host economies and societies.

Keywords: urban necropolis, migration, migrants, local economic development 


\section{Introduction}

In what ways do migrants shape their local spaces and contribute to the host economy and society? Years of global migration studies have established that when migrants are deemed to exert pressure on the facilities of the host communities, are unemployed, and make little or no contribution to the host economy and society - and they often are so deemed - negative attitudes towards migrants are considerably heightened, sometimes reaching feverish conditions (Markaki \& Longhi, 2013). The current "migrant crisis" in Europe, the Americas and elsewhere in the world exemplifies this view, highlighting how migrants are generally perceived: as unwanted. Evident in the discourse of "compassion" used by those few countries that are taking steps to welcome migrants is a testament that migrants are perceived to be parasitic or, in other words, recipients of socioeconomic benefits and underminers of security and political tranquillity. This negative sentiment is particularly acute in cities, where pressure on amenities is concentrated and more visible. In turn, migrant neighbourhoods around the world are commonly described as spaces for criminals, illegal and dishonest activities, poor housing, blighted conditions, crime, grime and insecurity (see Collins, 2008, 2013; Tsenkova, 2014; Opoko et al., 2015). Much of this perception is, however, negated by a few studies (e.g., Stilwell, 2003; Obeng-Odoom, 2012a, 2014) that show that the experiences of migrant neighbourhoods are more complex. The recent popular book Arrival City by Doug Saunders (2012) paints a picture of how migrants successfully go through the migration process - but this is popular writing and is methodologically committed more to individuals than to their social relations or migrant neighbourhoods generally (Davidson \& Gleeson, 2013). Insights from traditional rural-urban migration research (for a review, see Acharya \& Codina, 2012), especially those from mainstream economics, do not help because they tend to consider migration from the actions of individuals and households within national borders - clearly ignoring transnational migration, let alone transcontinental migration, and how this is mediated by structural and institutional factors and processes (Adogame \& Lawrence, 2013; Ozkul \& Obeng-Odoom, 2013; Portes \& Yiu, 2013). Where systematic transnational migration research has been conducted, it has focused much less on migrant neighbourhoods, on which the literature has been sparse and even then limited to refugees and their enclaves or townships (e.g., Stilwell, 2003). Although migration studies have revealed much about the characteristics of migrants in the labour force, they focus more on individual dynamics. Research on migration and the economy limits the economic perspective to growth, productivity and labour markets. Moreover, much of the research focuses on the situation in the UK and US (see, e.g., Riley \& Weale, 2006), and so analysing the role of migrants in transforming entire neighbourhoods (a different focus) and shifting the attention to Australia (a different advanced capitalist country) will help strengthen the understanding of the "economics of migration". This paper complements and significantly extends existing efforts to better understand migrant neighbourhoods and, in turn, sheds light on the role of migration in the socioeconomic transformation of migrant spaces and host economies and societies.

The empirical referent of the study is Lidcombe, a migrant neighbourhood in Sydney, Australia. The neighbourhood is located "in Auburn municipality and on the traditional lands of the Darug people, centres upon the railway station and a small shopping centre. It extends north to Parramatta Road and east to Rookwood Cemetery. On the western and southern boundaries it merges into Auburn and Berala. The land is fairly flat, but generally slopes down towards the Parramatta River" (Kass, 2008, no pagination). This focus is important in three ways. First, the study contrasts with the focus of research in Australian migration studies, which have tended to be centred mainly on migrant businesses (e.g., Collins et al., 1995), important labour conditions of temporary and permanent migrants (e.g., Hugo, 2008; McGrath-Champ et al., 2011) and the positive effects of remittances from migrants to their home countries (Obeng-Odoom, 2010), not their contribution to the transformation of neighbourhoods in Australia - except for a few notable exceptions (see, e.g., Stilwell, 2003). Second, it is the first to provide a scholarly study of Lidcombe as a migrant neighbourhood. The Sydney Journal has documented the experiences of other suburbs such as Berala (Gordon, 2008) and Croyden (Johnson, 2009), but even then not primarily from a migration perspective and definitely not the highly important neighbourhood of Lidcombe. Even the well-known Liberty Plains: A History of Auburn, NSW was criticised for overlooking Lidcombe in its 1983 and 1986 editions, prompting a revised edition in 1992 (see Hedges, 1992). That revision, however, missed the migration angle. As with the earlier editions, it is concerned more with the history of Lidcombe. Finally and more broadly, this study draws attention to processes, politics and policies that are often missing in the growing literature on cities and migration such as Triumph of the City (Glaeser, 2012) and Arrival City (Saunders, 2012), which has prompted many critical urbanists (see, e.g., Davidson \& Gleeson, 2013; Obeng-Odoom, 2013) to call for further and wider studies of the migration phenomenon in cities. The State of Australian Cities Report 2013 (Department of Infrastructure and Transport, 2013) bemoans the lack of understanding of the dynamics of migrant neighbourhoods in Australia, and Pau Serra's (2012) contribution to this journal stresses that much of North America has many migrants but research on 
how migrants transform urban and regional spaces is sparse or insubstantial.

The data informing this analysis are derived from 1) repeated discussion and conversation with people that have lived in the area over the last ten to thirty years, including railway workers, library staff, shopkeepers, residents and post office workers; 2) archival research at the Lidcombe and Auburn libraries to search for and examine past issues of the Auburn Review, which is the community newspaper for the area; 3 ) enquiries at realestate agencies in Lidcombe and nearby suburbs; 4) transect walks in the case-study area interspersed with visual ethnography to capture photographic information from plaques on historical or historic buildings; 5) church sermons; 6) statistical information taken from the Australian Bureau of Statistics bulletins and 7) various publications by the Auburn Council, the local authority of the neighbourhood.

The analytical framework is the historical-structural paradigm in migration analysis. In contrast to the neoclassical economics emphasis on individual rational factors as drivers of migration within an ahistorical profit-maximising narrative, the historical-structural paradigm emphasises migratory processes as part of structural change in society. The approach considers individual reasons for migration, but mainly as a dialectical relationship with group motives for movement, internally and externally, and is oriented towards inductive reasoning (Abreu, 2012). A version of this approach was successfully used by Frank Stilwell (2003) when studying the migration of Afghan refugees and its ramifications for local and regional economic development in the neighbourhood of Young in Sydney. Since then, at least nineteen other studies have followed with equal success or drawn on the work. ${ }^{[1]}$ Although this approach does not result in definite models with quantitative and categorical answers, and some economists oriented toward econometric analysis may thus regard it as weak (see, e.g., Molho, 2013), it has important strengths. It is more transparent and amenable to public scrutiny, and it is more "real world"-based because it embraces the diversity, uncertainty and complexity of factors often overlooked in restrictive neoclassical economics models based on contentious assumptions of homo economicus, winwin equilibrating conditions and perfect information (Stilwell, 2003) - all of which are inapplicable to the present study.

It was found that life in Lidcombe is substantially different from this stereotypical view. Lidcombe is located within, over, or across the largest necropolis in the southern hemisphere. According to cemetery records and inscriptions recorded during recent transect walks in the cemetery, over 800,000 people have been buried in the cemetery. Twenty-first century migration has transformed this neighbourhood - previously mainly regarded as a burial site for locals - into a vibrant and diversified local economy, with little crime and grime. Here is a story of an overall positive socioeconomic transformation driven by migrants. Lidcombe is now seen as the "home of the 2000 Olympics", the "headquarters of Korean churches" and a "home away from home". The cemetery still exists, as does a major funeral home, but they no longer constitute the mainstay of the local economy, which is currently highly diversified with economic activities such as food, retail, hairdressing, pharmaceuticals, real estate and entertainment activities gracing the streets. Unlike in 1904, when Lidcombe's population of 4,500 people were either White Australians or White people from the UK (Hedges, 1992), today the neighbourhood has over 15,000 people from over thirty countries and the local economy is powered by migrant enterprises. This successful transformation is not one of simple cause and effect. Migrants have contributed to the transformation, but they were drawn by other factors. Regardless, the transformation is simultaneously the neighbourhood's Achilles' heel: property prices have increased substantially and hence Lidcombe is no longer the affordable neighbourhood that welcomed migrants and assisted them in achieving their "Australian dream" a decade earlier.

The rest of this paper is divided into three sections. The following section is a socioeconomic history of Lidcombe, focusing on the period before the arrival of migrants. The second section examines the situation since the "migration age", looking at characteristics, activities and contributions of migrants, and the final section reflects on the implications of the transformation for resident migrants and other potential migrants.

\section{Lidcombe: The early days}

The social history of Lidcombe can be discussed around three themes and times; namely, the era of obscurity, the period of economic prosperity and the age of economic difficulty. Each of these is discussed in turn.

\subsection{The foundations of the neighbourhood and the era of obscurity}

Lidcombe is located in the western part of Sydney, Australia. The original land which it formed around was close to a creek, which belonged to a certain Samuel Haslam in 1804 . Haslam's Creek, as the area came to be called, was mainly inhabited by local Australians that had immigrated from the UK. They used the creek for domestic work and relaxed along its banks (Hedges, 1992). Sir Thomas Brisbane, George Tuckwell and George Sunderland were other landowners in the area between the early 1820 s and early 1830 s. As the account of John Mitchell (2008) shows, Father John Joseph Therry was, however, the landowner whose activities would change the course 
of Lidcombe. An Irishman and one of two Catholic priests appointed to do pastoral work in New South Wales during the colonial days, he was one of the first to purchase lots in the area now called Lidcombe. He did so for investment purposes - not so much for personal profit, but for the extension of his pastoral work, particularly because he had fallen out of favour with the Church and was no longer paid his GBP 100 annual salary. His business strategy was simple: buy low, sell high. Thus, he paid GBP 15 to Kirk in 1831 for a sixty-acre lot and GBP 40 to Sunderland in 1834 for a 160-acre lot.

An investment opportunity arose when lawyers for the Sydney Railway Company offered to buy ten acres of land from Therry for the construction of the proposed railway line from Parramatta to Sydney in 1855 . Therry took the offer and was paid GBP 100, a good price considering how much he had paid for the land. Other landowners in the area, determining that a railway station at Haslam's Creek would revive the local economy and push up property values, persuaded Therry to give further support to investment in the area. Therry was in favour of the idea and so was the railway authority, but the proposers had to bear the GBP 700 cost of establishing a train station. Therry contributed the GBP 100 he had obtained from selling his land to make the establishment of the station possible, and the others might have contributed the rest of the funds needed (Mitchell, 2008). Thus, Therry was not only someone that sold land for railway transport to start in Lidcombe but he also invested in its development. Haslam's Creek Station eventually opened in 1859 (Pollen, 1988).

The establishment of a suburb promptly began. According to the account by Stanley L. Hedges (1992), "completion of the railway radically changed the status of the district". Roads to make this district an independent suburb were constructed, the first being John Street in Lidcombe North, named after Therry in 1862. Another road was built and a subdivision, the "Town of St. Joseph", was announced, commencing the journey of settlement expansion (Hedges, 1992). The railway station was a major driver in propelling the (urban) development of Lidcombe.

In 1862, the New South Wales government purchased two hundred acres of land to establish what has been referred to as the "largest cemetery in the southern hemisphere" (Emerson, 2001: 24). The necropolis was completed in 1867 and was named Haslam's Creek Cemetery. Residents of the area fiercely protested linking their township's name and hence town to the burial grounds. The stigma was real. Typical comments included: "All you have to do is to walk over and drop in"; "The majority of people say, 'it will be time enough to go to that suburb when life is over"; "The town is run by tombstone men and gravediggers" (1904 observations about Lidcombe, quoted in Hedges, 1992: 232, 233).

It would seem that this discomfort may have informed how land in the area was marketed. It was quite common to offer land for sale in the "Town of St. Joseph surrounding Haslam's Creek Railway Station” (Hedges, 1992: 224) without making reference to the cemetery. The authorities responded to the protests by changing the name to Rookwood in 1878, after considering other names. Some say that the choice reflected the title of a book by William Harrison published around 1838 (Pollen, 1988; Emerson, 2001), but one newspaper account suggested that the name was chosen to reflect the abundance of a bird, the rook (which is similar to a crow) ${ }^{[2]}$ in the area, and was thus more appropriate than other names suggested, such as Fitzroy and Norwood (Hedges, 1992).

The Municipality of Rookwood was incorporated several years later, in 1891. Seven years after incorporation, residents began another wave of protests for the same reason: the link between the cemetery and the suburb, Rookwood Cemetery and the town or municipality of Rookwood. There were other negative markers of this area. For instance, in 1879, 1,340 acres of land were obtained in Lidcombe for a planned reform school. In 1893, it was converted into the Rookwood Asylum for the poor, elderly and feeble, whose conditions had been caused or aggravated by worsening economic problems, according to a plaque provided by the Australian Bicentennial Authority at the entrance of the gate house. However, it seems the major concern was with the name of the area. Accordingly, in 1914, the town was renamed Lidcombe as an amalgamation of the names of two former mayors, Lidbury and Larcombe (Pollen, 1988; Emerson, 2001). This name has remained.

The Great Depression of the 1930s took a massive toll on the town. Summed up under the caption "Depression Years", Alderman Stanley L. Hedges (1992) noted that those years repeated the nature of the Lidcombe economy in the 1890s. For the large number of poor people in Lidcombe in the mid- to late 1920s, the notion of a "depression" may have been strange because they had always been dependent on state support (unemployment benefits, but also non-monetary supplies such as blankets and military clothing) and the help of the Lidcombe Benevolent Society. Yet, the depression brought distinctive challenges. The council embarked on massive retrenchment and the wages of the remaining staff were reduced, adding to the challenges of a gloomy local economy. Terry Kass (2008) shows that some $23 \%$ of the residents of Lidcombe were out of work during the depression, forcing the Lidcombe Council to accept the government's "dole for work" programme by which people received welfare payments for work performed. Even 
then, many people remained unemployed and a "camp for the unemployed" had to be maintained between 1931 and 1932. So limited were employment opportunities that at one point the council had to use "draws" to allocate the few jobs available and there were enough unemployed people to form the Lidcombe Unemployed Workers' Union (Hedges, 1992). As noted by Kass (2008), soup kitchens were organised for children and those out of work.

\subsection{The era of prosperity}

The 1940s were a golden era for Lidcombe. In the words of one long-time resident, Lidcombe was "a bustling enterprising suburb, that had it's [sic] own council and a close knit community spirit" (Auburn Review, 1988, no pagination). A cooperative Building Society was established to kick-start a massive housing programme, making it possible for many residents to become homeowners (Hedges, 1992). Lidcombe was prosperous in the sense that the local economy was booming and the residents were employed either in or outside the town. The town had its own bakeries and dairy farms, delivery services and an aircraft engine factory. The town council had an ambitious programme to improve the quality and quantity of housing - a complement to "an extensive programme to improve the streets of Lidcombe by Kerbing, Guttering and Asphalting Footpaths" commenced in 1929 and sustained even until 1937 (Hedges, 1992: 285) and beyond. According to local accounts, at one point, there were six banks in the town. Fruit stands, shoe stores and women's clothing stores boomed, as did groceries. At one point there were five bakeries in Lidcombe alone. The residents worked for the railways, the hospital and the cemetery - all in Lidcombe - and at a major slaughterhouse in what is now Olympic Park (Figure 1). The state slaughterhouse generated employment for 1,600 people, including substantial numbers from Lidcombe (Hedges, 1992). Others were employed in major industries and business units in or around Lidcombe. Examples of such companies were Ford, Australian Forge, Dahaviland, Janson's, Bradford Insulation, Australian Electrical Industries, Dairy Farmers, Barbcock \& Wilcox, Egg Board, Tooyer's Brewery and Coats Printing. Socially, the population was small but cohesive and enjoyed camaraderie, which, in turn, made crime rare.

The economic expansion in Lidcombe was accompanied by efforts to ensure continuing community connectedness. In turn, dance clubs were formed and sports activities were organised. At home and at work, the trilogy of "respect, responsibility and discipline" was strictly taught and upheld by both young and the old, a point emphasised by two long-time residents. At the town governance level, a decision was made to enhance efficient management by merging Lidcombe with Auburn in 1949 to form the Auburn Municipality (Emerson, 2001).
This was a controversial decision because some residents and even councillors considered the merger unwise - among other reasons, because Lidcombe would have to shoulder debts it had not incurred (Hedges, 1992). Nevertheless, the merger went on and, at the time, did not seem to constitute a break in progress at home, at work or at the level of town administration.

Lidcombe's era of prosperity was organically linked to the boom that the Australian economy as a whole was enjoying during the period. This post-Second World War boom (1945-1975) was not linked with imperial Britain's economic architecture, although Britain, the colonial landlord of Australia, founded the Australia settler colony and supplied it with labour and capital from 1788 to the 1890s. Between 1946 and 1948 and between 1966 and 1968, there was a 65\% decline in the share of Australia's exports to the UK and a $56 \%$ fall in imports from the UK (Broomhill, 2008). Australia looked to the US, the new global power, and to Asia, its neighbour, for trade and even cultural exchange. Increasingly, foreign companies opened branches in Australia not only to partake in the boom but also to contribute to it (Broomhill, 2008). Consistent with the prevailing view at the time, the Australian government embraced Keynesianism and expanded the arm of the public sector in providing housing and health, education and food subsidies to Australians (Broomhill, 2008). The boom created a need for migrant labour. Thus, after 1947, the Australian government embarked on an active policy to recruit settler migrants. Immigration then accounted for roughly half of the population growth in Australia. Europeans, particularly British, and Oceanians, especially New Zealanders, were the most visible in the stream of migrants that responded to this policy initiative (Collins, 2008). The end of the boom and the commencement of Australia's second cycle of decline, which one informed political economist (Broomhill, 2008: 21) calls "the crisis of the 1970s and 1980s", were also felt in Lidcombe.

\section{3 "Let Lidcombe live again"}

The Auburn Review of 1988 carried a story captioned "Let Lidcombe live again!" that captured the mood of that era. The person interviewed for the story was the publicity officer of the Lidcombe Community Improvement Association and former alderman, Keith Huteau. He talked of the death of the Lidcombe Chamber of Commerce and his desire to see its revival. His diagnosis of the problem is even more telling. According to the paper, "He said the death knoll of Lidcombe was the introduction of the new expressway, which he said had taken the main stream of customers away from Lidcombe shopping centre". Two long-term local residents with whom Huteau's diagnosis was discussed for this paper agreed, but offered a further explanation. The expressway had been responsible for the demolition of businesses and some houses, and hence took 
away not only business but also some of the social "good old days" feeling from the neighbourhood.

There are other reasons that have been put forward to explain the decline. Some residents suggest that the removal of the centre of administration from Lidcombe also took away some of the shine from the suburb. It definitely did lead to the demise of town hall activities, but because this happened in 1949 its effects may have taken time to be felt. At the more national and global levels, factories that hitherto employed Lidcombe residents were shutting down or moving to other locations to save costs, including trade union demands for better and higher wages. Internationally, oil price increases and advances in production techniques increased production costs and diminished the volume of purchases from Australia, exports from which had included substantial amounts of primary agricultural or raw materials (Stilwell, 1998; Boomhill, 2008). Among the businesses mentioned above, only Tooyer's Brewery and Coats Printing have remained. Others, like the Royal Australian Airforce, continue to have a presence in Lidcombe, but they are dormant. Regardless of the precise cause, by 1988 and through the 1990s, socioeconomic activities in Lidcombe were down. The banks left and, with them, jobs. The roads were in poor condition and the government was beginning to withdraw its hand to be replaced by the invisible hand of the market. Public houses near George's Avenue were sold off - consistent with the view that a "slim" government was best - or what the Australian authorities called an "economic rationalism" paradigm (Stilwell, 1979, 1998).

Relative to other years, migration to Australia was generally on the low side around this time (Collins, 2008). The political interest in globalisation was producing contradictory outcomes, especially in terms of concentrating wealth in the hands of a few people and making the majority of people worse off. The suburbs, especially those in the western part of Sydney (including Lidcombe), were not prospering and in fact seemed to be bearing the brunt of the forces of globalisation beginning to gain prominence in modern Australia. Business entities favoured the "importation" of migrant workers to fill shortages at the same time (Stilwell, 1998). Starting in 2000, however, there was a boom in migration to Australia (Collins, 2008) and, according to local accounts, to Lidcombe as well. Local Australian factors, especially the Olympics, were powerful magnets but there were strong push factors too. The 1997-1999 Asian crisis, for instance, led to considerable emigration from Asia (Castles, 2008). However, whether push or pull, 2000 was a watershed in the life of Lidcombe.

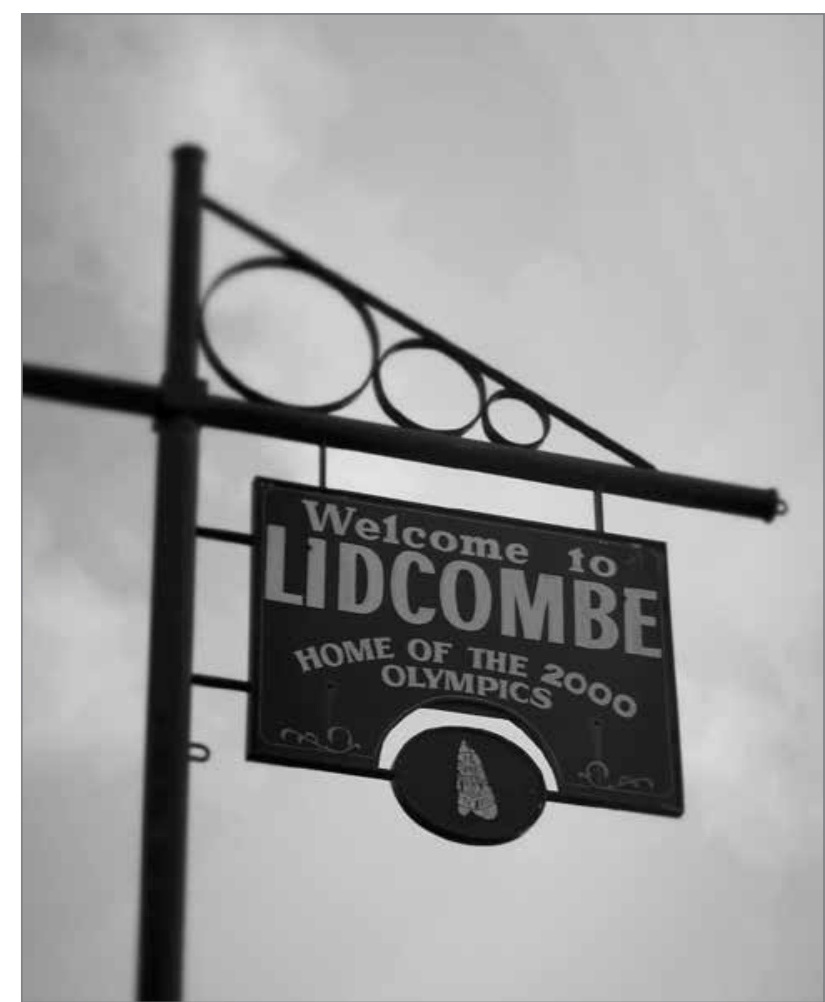

Figure 1: Lidcombe and the 2000 Olympics (photo: Hae Seong Jang).

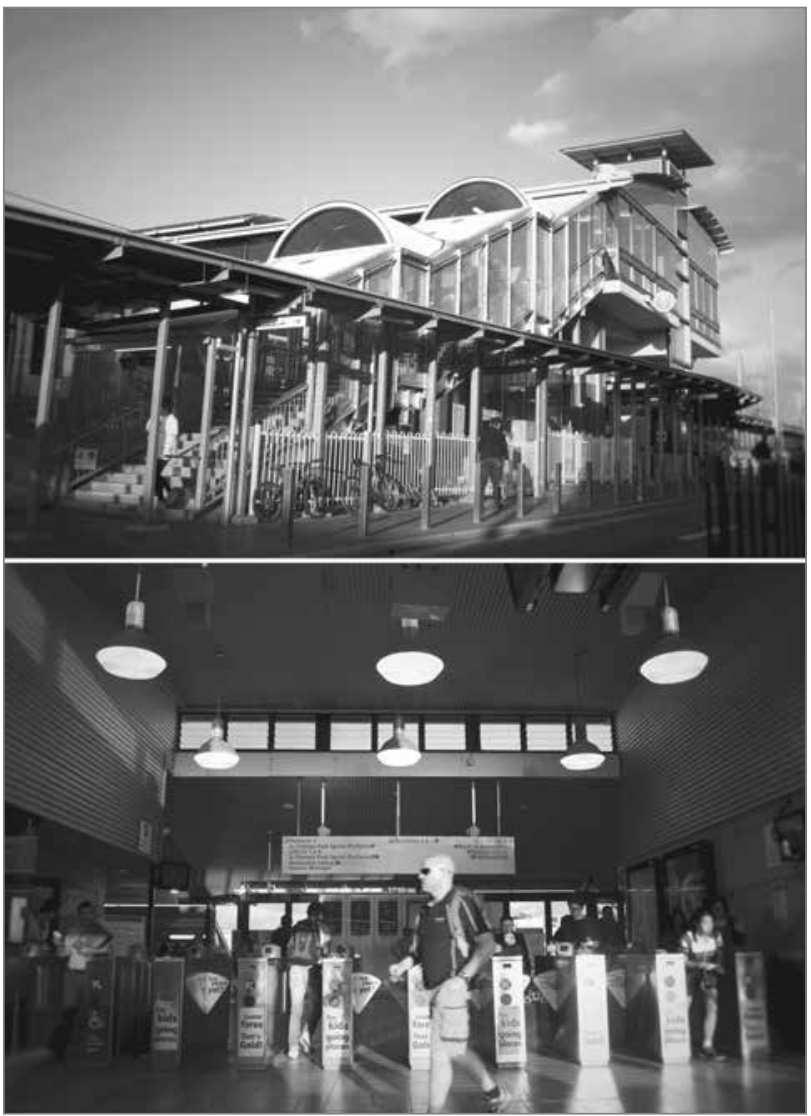

Figure 2: Modern railway in Lidcombe (photo: Hae Seong Jang). 


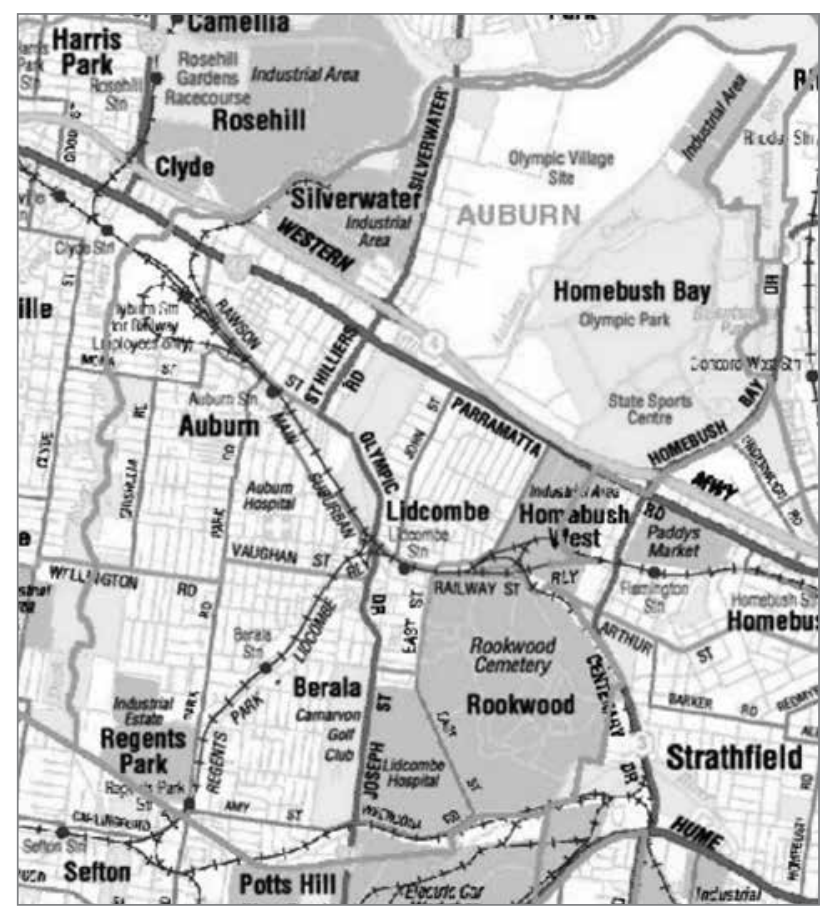

Figure 3: Map of Lidcombe (source: Division of Local Government, Department of Premier and Cabinet, 2013).

\section{Moving into a "dead city": Lidcombe after 2000}

The 2000 Sydney Olympics changed the face of Sydney and its suburbs. One researcher described the mood after the announcement that Sydney would be the site for the 2000 Olympics as "jubilant" (Handmer, 1995: 355). The Olympics propelled the Auburn Municipality as a whole, leaving in its wake urban projects that would generate income for the city authorities. Of the four hotels in Lidcombe now, at least two were built in the lead-up to the Olympics, making the Olympics a symbol of the neighbourhood (see Figure 1).

Houses were constructed and an Olympics platform, lifts and a major highway (Olympic Drive) were developed to welcome visitors and entice some of them, at least, to consider taking up residence in the neighbourhood. Sales of tickets went up, visitors rented places in Lidcombe and, importantly, Lidcombe received considerable attention both locally and nationally. The Olympic railway line was opened and traffic in Lidcombe increased. Being a junction station, Lidcombe was gradually showcased to the world and to other migrants in Sydney previously not living in Lidcombe as a prosperous neighbourhood connected to other parts of Sydney. A modern railway system (see Figure 2), the Lidcombe Railways, has continued to be an important aspect of life in Lidcombe after 2000.

A few non-UK migrants had lived in Lidcombe before 2000, of course. The first non-English-speaking migrants to Lidcombe were Russians, Croatians, Ukrainians and Poles (Ashton, 2008). Italians were also among the first to come, establishing a meat factory on Joseph Street when they arrived. There were enough Ukrainians to warrant the establishment of a large Ukrainian Church on Church Street in 1958, as well as a Youth Centre on Church Street and a High School on Joseph Street. The first major wave of migrants in Sydney as a whole must have been in the 1960s following the long postWorld War Two boom in the Australian economy (Ashton, 2008). The point is that Lidcombe was not first discovered by migrants in the post-2000 era. Rather, the twenty-first-century wave of migration in Lidcombe was distinct in terms of numbers and diversity. Currently, migrants - people born in areas where English is not the first language - constitute 59\% of the population of Lidcombe (Auburn City Council, 2013b), which is part of the broader Auburn Municipality made up of other suburbs, prominent among which are Auburn, Berala, Homebush Bay, Regents Park and Silverwater (Auburn City Council, 2013b).

Currently, much of the population of Lidcombe has immigrated from non-English-speaking countries. Although a substantial share of the migrant population is Asian, migrants come from more than thirty countries from around the world ( $\mathrm{Ta}$ ble 1). Thus, it is different from the typical Australian migration flow dominated by the UK and New Zealand (Collins, 2013).

As shown in Table 1, there have been notable shifts in the population mix in Lidcombe. The decline in the share of population from Lebanon, Turkey, Croatia and the UK is particularly substantial and hence requires some analysis. Local accounts say that the Lebanese numbered more than they do at present, but as Chinese migrants, with a longer history in Sydney and Australia than other migrants, started purchasing land and housing in Lidcombe for investment purposes, they were pushed out according to real-estate agents. The Chinese would knock down run-down buildings, redevelop and sell them for profit. In turn, prices of real estate started soaring faster than others living in Lidcombe could afford but slower than what was happening in other parts of Sydney; for example, in Auburn. This process commenced in the mid- to late 1990s with the announcement of plans for and execution of massive development related to the Sydney Olympics of 2000 (Randolph et al., 2005).

Much has been written about gentrification in this journal (e.g., Kotze, 2013; Gunter, 2014; Monare et al., 2014; Marais, et al., 2014; Tsenkova, 2014), but the experience of Lidcombe warrants careful attention. Its process of gentrification is quite similar to the transformation of urban and suburban development in Sydney in the sense that it pushed 
out poorer people in areas adjoining the Olympics site and drew in richer people (Stilwell, 1998), although it is peculiar in the sense that money and migrants mingled to produce a distinct urban form, not only by pushing people out but also by populating a sparsely populated suburb.

The process of migrant gentrification cannot explain the special case of Lebanese and Turkish migrants. For them, research (Burnley, 2006; Mourad, 2009) suggests that the completion of the Auburn-Gallipoli Mosque in 1999 pulled Turkish migrants, including some of those in Lidcombe, to move to Auburn. The mosque, which is a major religious meeting point for Muslims in the area from Lebanon, Turkey or elsewhere, was substantially financed by the government of Turkey with support by local Muslim migrants. It attracted some Turkish and Lebanese migrants in Lidcombe to move to Auburn not only because some could find accommodation in residential facilities also owned by the mosque administration but also because a larger population of Muslims, Lebanese and Turkish live in Auburn, creating a "home away from home" and setting in motion a powerful magnet for increasingly more Muslim migrants from Turkey, Lebanon and elsewhere to congregate.

The "religious factor", however, is a poor explanation for the decline of the Croatian population in Lidcombe between 2001 and 2008. Rather, as shown by research by Val Colić-Peisker (2004) and Walter Lalich (2004) published in the Croatian Studies Review together with local accounts and the analysis by Ilija Šutalo (2004) in his book Croatians in Australia: Pioneers, settlers and their descendants, the changing nature of migrants from Croatia is a better explanation. Unlike the earlier Croatian migrants, who were mainly working class and found the suburb and its cheap housing with gardens comforting, and hence stayed in the suburbs for a longer time, the younger and newer groups of migrants with better English skills, better professional qualifications and better potential to increase their incomes stayed in the suburbs for only a while and then moved to better localities. Working-class migrants continued to migrate to Australia, but Lidcombe was no longer attractive, given its growing apartment housing, which the Croatians did not find ideal for family life. Moreover, Croatians in Sydney had invested heavily in providing community facilities outside of Lidcombe, including religious, educational and entertainment facilities, all of which contributed to making Lidcombe a less ideal place.

A modified version of the "push out" hypothesis can be offered to explain the substantial decline in the share of migrants from the UK that reside in Lidcombe. Although substantial numbers of White Australians in Lidcombe moved out in this process, they were not simply pushed out by richer migrants. For some migrants, the White residents moved out because they
Table 1: Demographic profile of Lidcombe, 2001-2011 (\%).

\begin{tabular}{|c|c|c|c|}
\hline Birthplace & 2001 & 2006 & 2011 \\
\hline China & 9.5 & 10.5 & 11.3 \\
\hline South Korea & 3.2 & 3.5 & 10.5 \\
\hline Vietnam & 7.9 & 6.9 & 6.2 \\
\hline India & 2.2 & 2.0 & 3.0 \\
\hline Philippines & 2.9 & 2.8 & 2.9 \\
\hline Sri Lanka & 2.9 & 3.3 & 2.7 \\
\hline Lebanon & 4.6 & 4.0 & 2.7 \\
\hline Turkey & 2.7 & 2.5 & 1.9 \\
\hline Nepal & 0.1 & 0.6 & 1.7 \\
\hline Hong Kong & 1.3 & 1.3 & 1.6 \\
\hline New Zealand & 1.6 & 1.5 & 1.2 \\
\hline Malaysia & 0.7 & 0.7 & 1.1 \\
\hline Burma & 1.4 & 0.9 & 1.1 \\
\hline Pakistan & 0.5 & 0.6 & 0.9 \\
\hline Indonesia & 0.4 & 0.5 & 0.9 \\
\hline Afghanistan & 0.2 & 0.6 & 0.8 \\
\hline Bangladesh & 0.2 & 0.4 & 0.6 \\
\hline Croatia & 1.2 & 0.7 & 0.6 \\
\hline United Kingdom & 1.1 & 0.7 & 0.6 \\
\hline Fiji & 0.9 & 0.6 & 0.6 \\
\hline Cambodia & 0.4 & 0.4 & 0.5 \\
\hline Iraq & 0.6 & 0.9 & 0.5 \\
\hline Tonga & 1.1 & 0.9 & 0.4 \\
\hline Singapore & 0.1 & 0.4 & 0.4 \\
\hline Taiwan & 0.4 & 0.2 & 0.4 \\
\hline Thailand & 0.3 & 0.3 & 0.4 \\
\hline South Africa & 0.1 & 0.2 & 0.3 \\
\hline Egypt & 0.2 & 0.3 & 0.3 \\
\hline United States & 0.1 & 0.1 & 0.3 \\
\hline Iran & 0.3 & 0.3 & 0.3 \\
\hline Italy & 1.0 & 0.6 & 0.3 \\
\hline Ireland & 0.3 & 0.2 & 0.3 \\
\hline
\end{tabular}

Source: Auburn City Council (2015a).

were not willing to mix with the incoming migrant groups. Others contend that the shops for White Australians were not doing well with the arrival of migrants that typically shopped at migrant outlets instead of Australian stores, and so Australian shopkeepers relocated - shops and all. A perception that Lidcombe is for migrants may be another reason dissuading the White population. Attrition is certainly one of the many reasons, as old-time residents passed away and their children moved out. The subsequent lack of interest in a suburb predominantly filled by and regarded as being for migrants is yet one more reason. Recall, however, that Lidcombe had always 


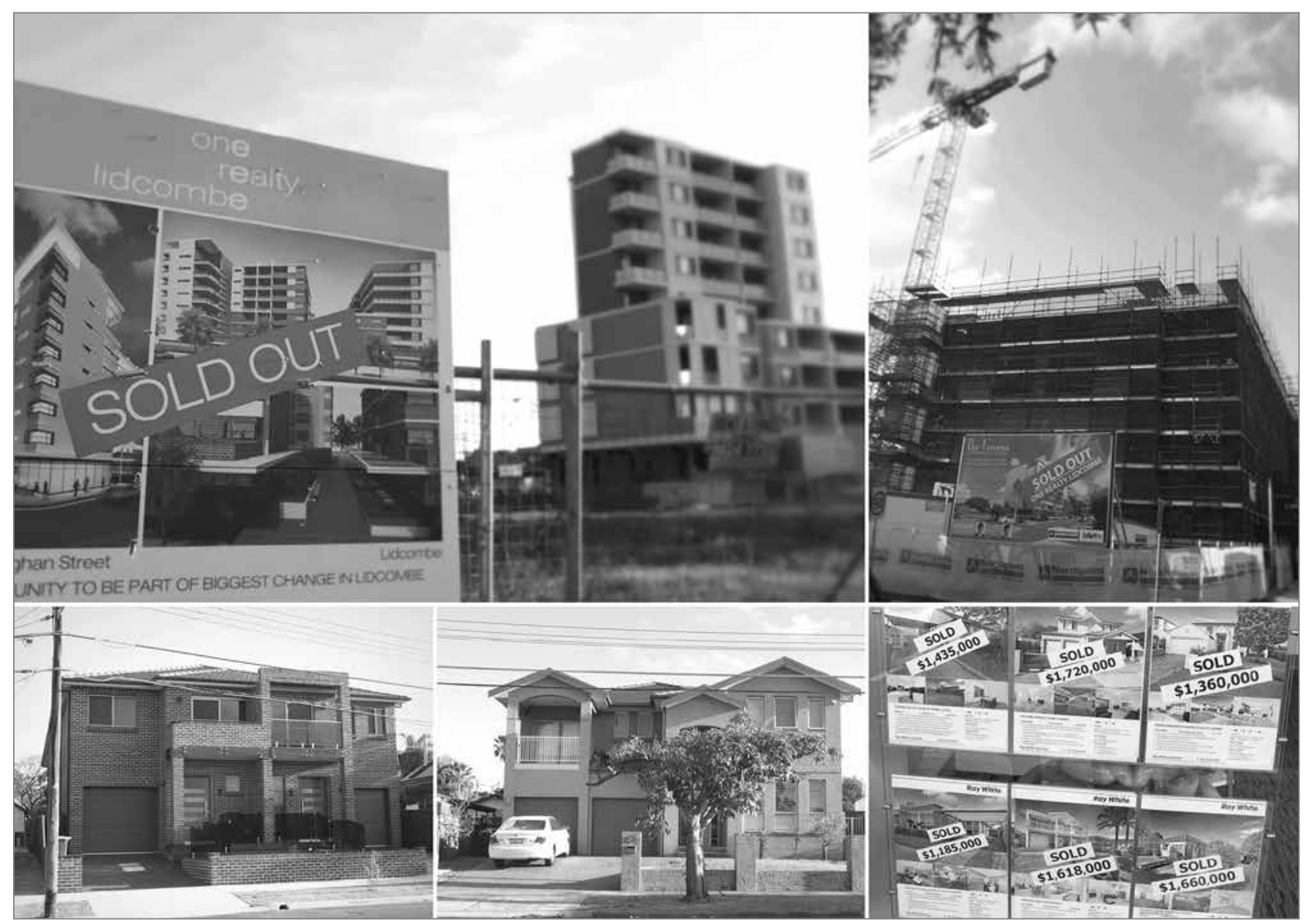

Figure 4: Property and apartment development in Lidcombe (photo: Hae Seong Jang).

Table 2: Lidcombe: Population and migration trends, 2001-2011.

\begin{tabular}{llll}
\hline Year & 2001 & 2006 & 2011 \\
\hline Population & 13,454 & 14,148 & 16,403 \\
\hline Female (\%) & 49.5 & 49.7 & 49.1 \\
\hline
\end{tabular}

Source: Auburn City Council (2015b).

had a stigma of being a "City of the Dead", so it has never been a location of choice for White Australians. As noted earlier, the Anglo population that moved in during the formative years of the city primarily worked in the cemetery (Hedges, 1992) or for the railways (Mitchell, 2008), the slaughterhouses or the factories that abutted or existed within Lidcombe. Some of the White population left because they sold their properties to migrants for a profit. Others may have moved out to enable their children to attend better schools, or no longer had any children to attend local schools, and a few may have chosen to live elsewhere. Thus, a combination of reasons, rather than one overarching driver, explains the decline of the White population in Lidcombe - although, as suggested by Burnley (2006), the concentration of high-class, all-White neighbourhoods in Sydney has always provided strong support for the view that race and class interact to structure settlement patterns in the city.
Table 1 also shows that there has been a growing share of certain nationalities in Lidcombe, although the neighbourhood remains very diverse in its population base. The most gain is in the Korean population. A major reason for this shift is that the price of real estate in Strathfield, a nearby neighbourhood whose population is dominated by Koreans, has become increasingly less affordable. Lidcombe, then, has offered an escape route from a heating-up property market in Strathfield. Of course, the increasing Koreanisation of Lidcombe is itself a magnet to pull other Koreans to Lidcombe. That said, the population and social culture in Lidcombe are diverse, including the coexistence of different types of churches (Figure 5). One physical location where diversity is literally on display is in the Lidcombe Remembrance Park (see Figure 6), where people from all nationalities meet for social activities, relaxation and light exercise. A popular Lidcombe Public School song captures the mood better:

We are from Lidcombe School (clap! clap! clap!) . . . learning in harmony is what we do best! Our students come from many different lands. United on Australian soil is where we choose to stand. Respecting one another and everyone we meet. Learning in harmony makes our lives complete. 


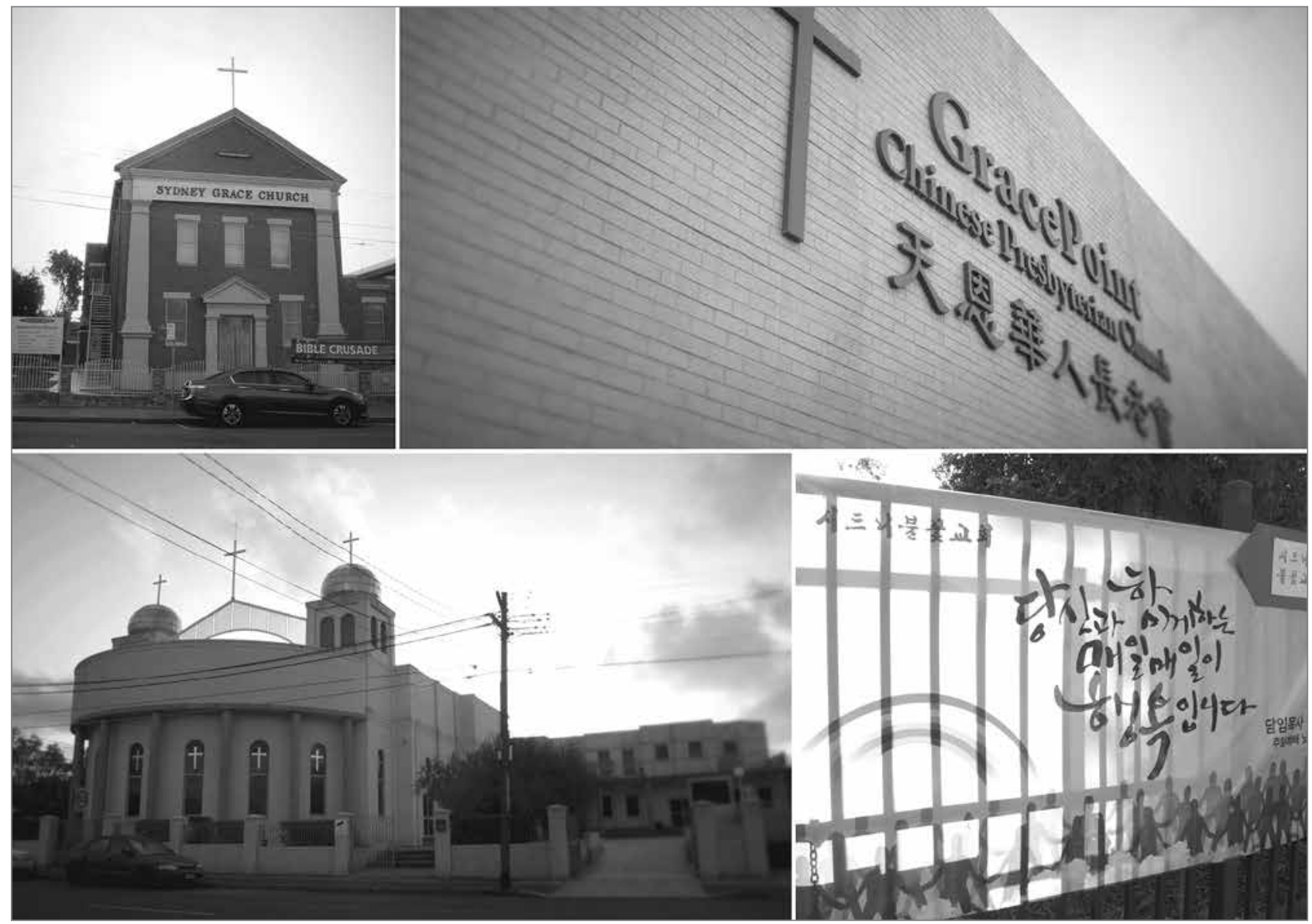

Figure 5: A sample of churches in Lidcombe (photo: Hae Seong Jang).

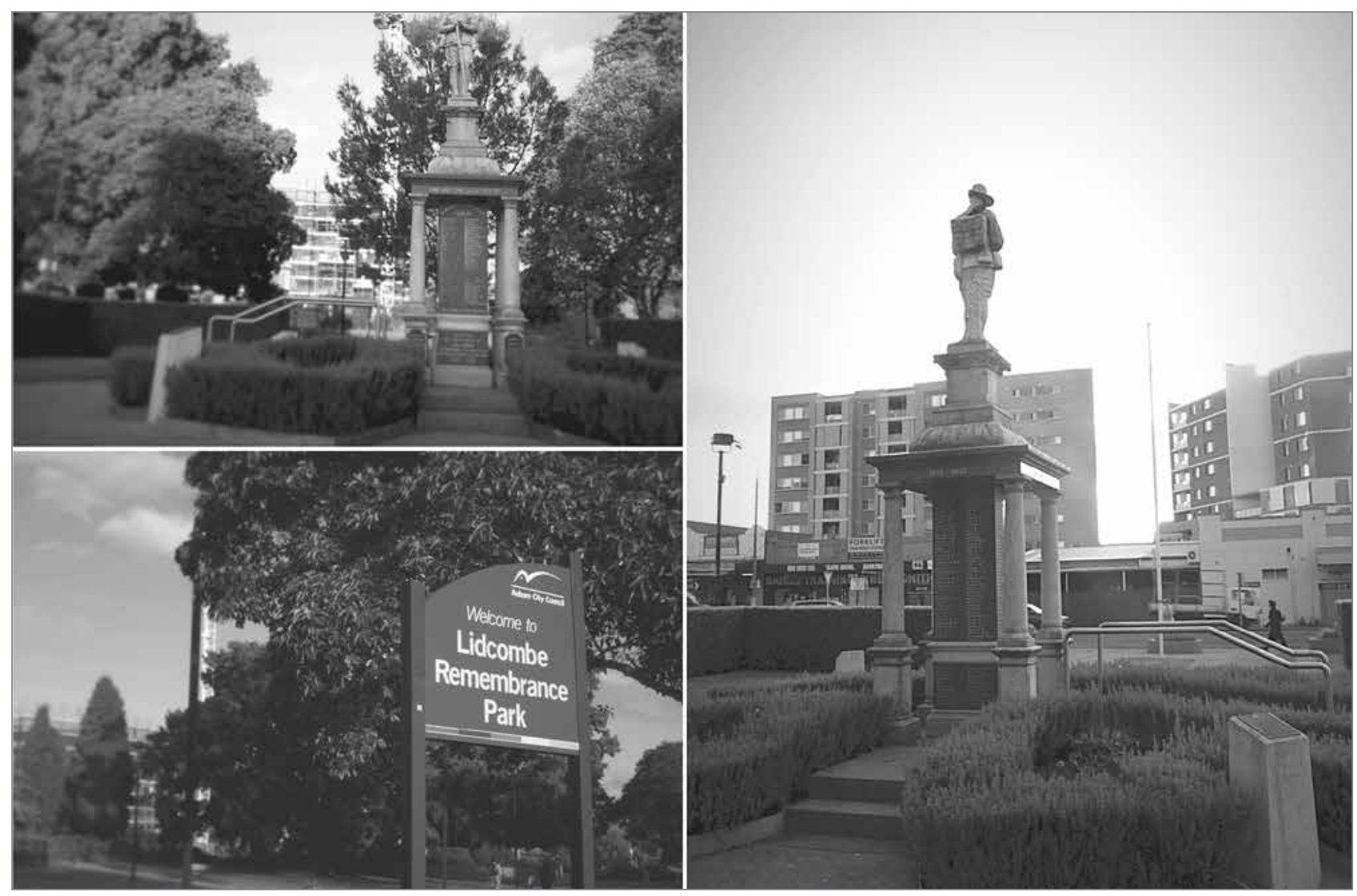

Figure 6: Lidcombe Remembrance Park (photo: Hae Seong Jang). 


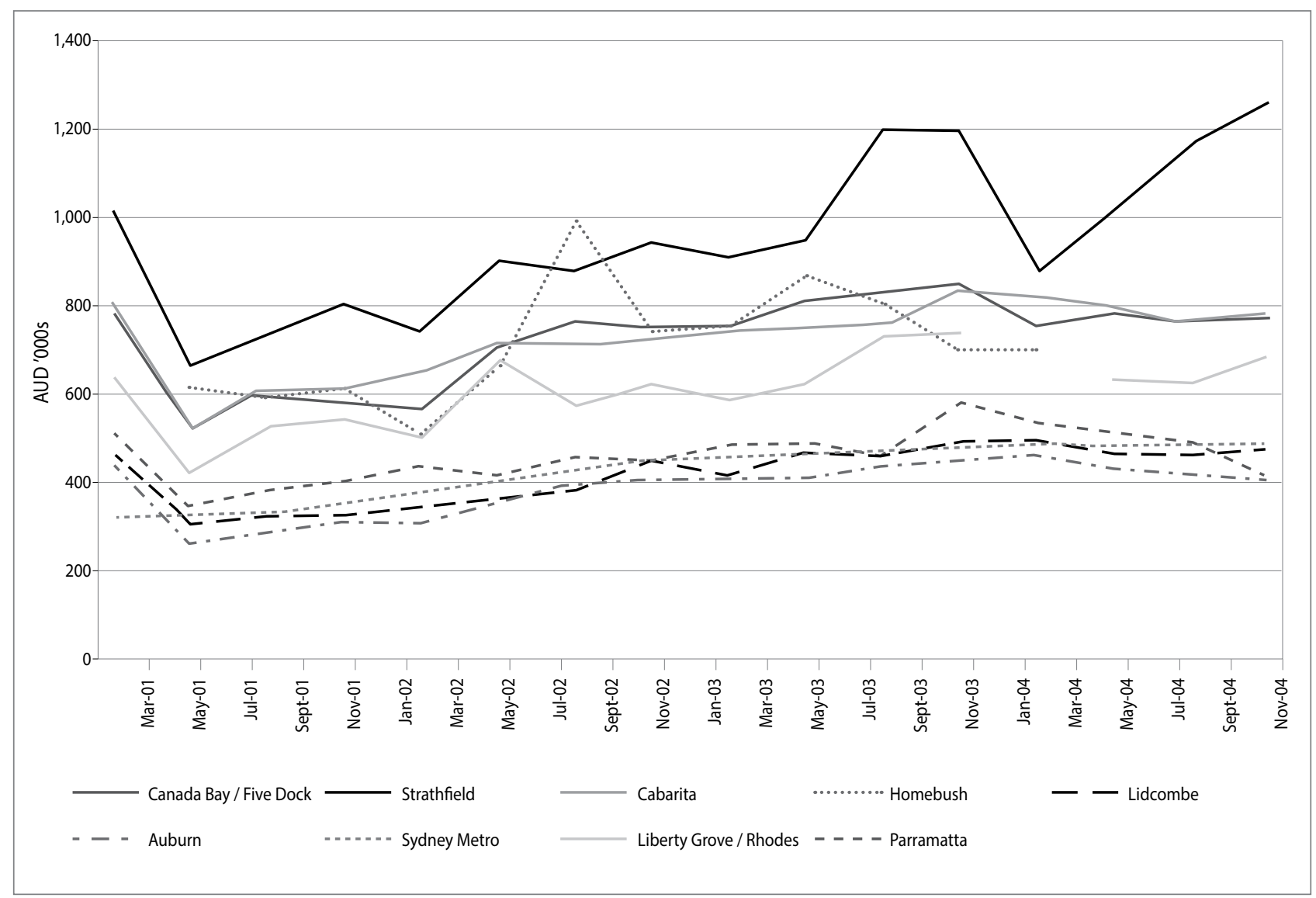

Figure 7: Median sale prices of surrounding suburbs in Sydney, 2001-2004 (source: Randolph et al., 2005).

Because students in Australia can only attend public schools in their local government area, the lyrics to this song complement the statistical information about diversity. Compared with the sparse population of the past, Lidcombe is now bustling with human activity and population growth, as shown in Table 2.

These figures exclude tourism, which is also substantial. Local accounts and systematic urban research (Stilwell, 1998) indicate that the population growth in Sydney and its suburbs is driven by immigration; the original White population in Lidcombe must be in decline both numerically and proportionally. A common reason for the increase in the migrant population in Lidcombe, according to the accounts of some migrants, is relatively cheap housing and easy access to other parts of Sydney because of the train station. Another reason is that an increase in the population of particular groups begets further increases because others are attracted to the location for a variety of reasons, such as the provision of enticing information, the community and other social support. The increase in housing prices elsewhere, notably in Strathfield, which is a suburb near Lidcombe (see Figure 1), also pushed away some migrants to Lidcombe (Han \& Han, 2010). Migrants, however, have favoured the neighbourhood. Housing in Lidcombe is relatively cheap compared to other suburbs, as Figure 7 shows.
Second, Lidcombe is accessible to the CBD and other locations where migrants work, shop and socialise. Third, it is a migrant neighbourhood. Although this third reason may sound circular, migrants have tended to gravitate towards areas known to offer social, religious and economic support, contrary to neoclassical economic theories about how migration is an individual rational affair (Molho, 2013). These reasons were commonly given by real-estate agents, operators of shops, railway workers and post office workers. A pastor of a Korean church, predominantly attended by Koreans and in whom church members confide, also preached a sermon on 12th January 2014 on the topic: confirming the three reasons, but adding a fourth: that God had brought the migrants to Lidcombe for the neighbourhood's transformation.

There is wide variation in push factors applicable to countries of origins. Different and sometimes similar conditions apply to the over thirty nationalities that live in Lidcombe today (see, e.g., Han \& Han, 2010 for Korean migration to Sydney and Moustafine, 2011 for Russian migration to Sydney). Taking the Korean case as an example, the ban on migration was lifted in the late 1990s, paving the way for greater emigration.

Migrants have typically moved in as families, although many single individuals have come in too. According to the commu- 
Table 3: Lidcombe (Southern Lidcombe/Rookwood Area): Employment statistics, 2001-2011.

\begin{tabular}{llll}
\hline Employment status & 2001 & 2006 & 2011 \\
\hline Employed & $2,288(90.5 \%)$ & $2,326(91.9 \%)$ & $3,421(90.4 \%)$ \\
\hline Employed full time & 1,549 & 1,619 & 2,175 \\
\hline Employed part time & 615 & 613 & 1,084 \\
\hline Hours worked not stated & 124 & 94 & 162 \\
\hline Unemployed & 239 & 204 & 361 \\
\hline Looking for full-time work & 151 & 139 & 186 \\
\hline Total labour force & 2,527 & 2,530 & 3,783 \\
\hline
\end{tabular}

Source: Auburn City Council (2015c).

nity profile on household size (Auburn City Council, 2013b), currently only $15 \%$ of households have a single member. The rest have two people (26\%), three people (21\%), four people $(21 \%)$, five people (9\%), or six or more people (7\%). Broadly, these figures are also similar for Lidcombe. Such group migration challenges the individual-based explanations and its dominants and domino effects or versions in neoclassical economics (Molho, 2013) and Australian migration policy (Collins, 2013). The evidence that only one recruitment company, Max Employment, has registered 1,400 job seekers (Auburn Review, 2014) shows that migrants are not only waiting for the dole. Their contribution to local, municipal and urban economic development has been substantial, contrary to claims that they are a drain to the Australian economy.

\section{The local, municipal and urban economy}

The unemployment rate in the entire Auburn Local Government Area is 5.6\% (Auburn Review, 2014), much lower than the national average of 6.0 or 6.1. It is important to zoom in on the neighbourhood itself. Taking the southern part of Lidcombe alone, which is an important example because it has historically been much less developed and desired than the northern part, Table 3 shows that a majority of residents in Lidcombe are employed, either on a full-time or part-time basis, and working either in Lidcombe or outside of the neighbourhood. Table 3 offers statistical information on the employment status of the population.

In 2011, 63\% of the population was of working age (20 to 59 years old) in both Rockwood and Lidcombe in general. Thus, the demographics are quite similar for both areas and they suggest that the migrants do not exert excessive pressure on public funding for retirees and migrant seniors. Residents work in a range of occupations, with manual labour (the stereotyped job for migrants) being only one of them. There are professionals and managers, technicians and trade workers, clerical and administrative service workers, and sales workers. Details of the share of these occupations are presented in Table 4.
Table 4: Occupational structure of Lidcombe (\%)*

\begin{tabular}{lll}
\hline Occupation & 2006 & 2011 \\
\hline Managers & 8.4 & 8.2 \\
\hline Professionals & 17.8 & 23.1 \\
\hline Technicians and trade workers & 14.2 & 14.4 \\
\hline Community and personal service workers & 7.5 & 8.3 \\
\hline Clerical and administrative services & 15.8 & 14.5 \\
\hline Sales workers & 9.2 & 8.4 \\
\hline Machinery operators & 9.3 & 6.7 \\
\hline Labourers & 14.7 & 12.4 \\
\hline Insufficient information & 3.3 & 3.8 \\
\hline
\end{tabular}

Note: * Figures apply only to the southern part of Lidcombe.

Source: Auburn City Council (2015d).

This evidence is not sufficient to know how vibrant the local economy is. Not all employed people work in Lidcombe, a feature of the suburb that has been systematically determined by the city authorities in its community profile (Auburn City Council, 2013b). The evidence can be complemented by looking at the large flow of people that leave the neighbourhood and entrain for other destinations during rush hours at Lidcombe Station. Similarly, the sudden influx of people from outside Lidcombe around 6 to $7 \mathrm{pm}$ on weekdays shows that not everyone living in Lidcombe works in the city. However, the combined effect of the movement in and out of Lidcombe suggests that some migrants' expenditures (e.g., on shopping and eating at work) impacts other local economies outside of Lidcombe, including the greater Auburn City municipality and elsewhere.

We do not have a record of the quantitative contribution of Lidcombe because the Australian Bureau of Statistics from which the City Council collates its data does not seem to offer this finer detailed information. Qualitatively, however, we know that Lidcombe itself has a variety of occupations: sales are the most conspicuous and most visibly active in serving the local population and people elsewhere, and so migrants' expenditures impact the local economy more directly. Joseph Street, a commercial hub of the neighbourhood, is lined with 

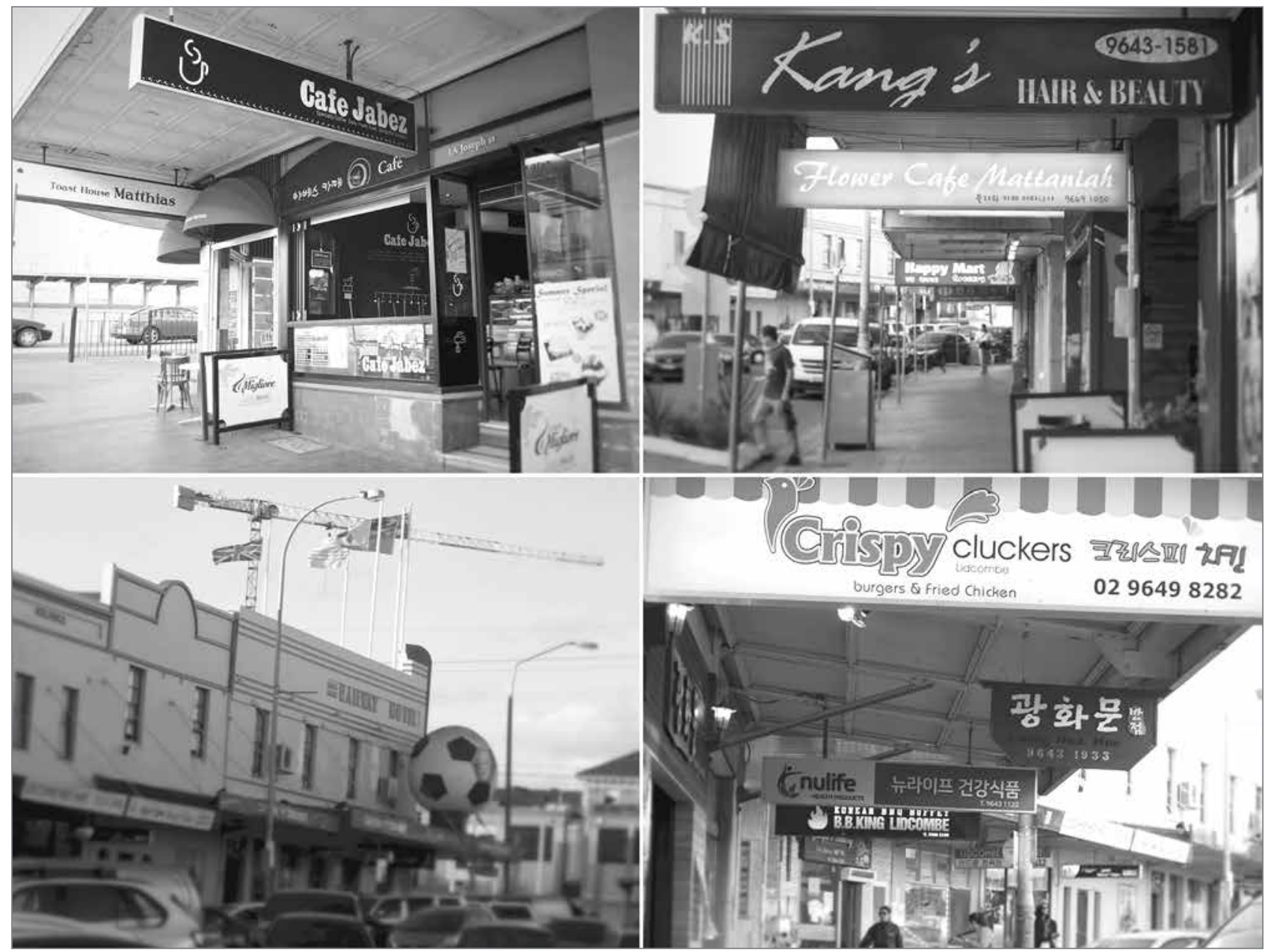

fried Chicken

0296498282

Figure 8: A major commercial precinct in Lidcombe (photo: Hae Seong Jang).

Table 5: Household income quartiles of Lidcombe, 2001-2011.

\begin{tabular}{|c|c|c|c|c|c|c|}
\hline Lidcombe & 2001 & Middle class & 2006 & Middle class & 2011 & Middle class \\
\hline Quartile group & $\%$ & & $\%$ & & $\%$ & \\
\hline Lowest group & 23.0 & \multirow{4}{*}{54.4} & 25.2 & \multirow{4}{*}{-53.8} & 23.2 & \multirow{4}{*}{54} \\
\hline Medium lowest & 26.9 & & 26.9 & & 26.9 & \\
\hline Medium highest & 27.5 & & 26.9 & & 27.1 & \\
\hline Highest group & 22.5 & & 21.0 & & 22.9 & \\
\hline
\end{tabular}

Source: Adapted from Auburn City Council (2015e).

Table 6: Key to interpreting household income quartiles, 2001-2011.

\begin{tabular}{llll}
\hline Household income ranges (AUD) & 2001 & 2006 & 2011 \\
\hline Lowest group & $0-418$ & $0-530$ & $0-614$ \\
\hline Medium lowest & $419-828$ & $531-1,034$ & $615-1,233$ \\
\hline Medium highest & $829-1,462$ & $1,035-1,788$ & $1,234-2,272$ \\
\hline Highest group & $1,463+$ & $1,789+$ & $2,273+$ \\
\hline
\end{tabular}

Source: Auburn City Council (2015f). 
shops, groceries, a bakery, hairdressers, restaurants, bars and a pharmacy. Joseph Street also has businesses, such as a medical practice, a tax agency, legal services and bars. Also available is the multinational fast-food provider McDonald's. Victoria Street East has a small industrial base, a modest business park and a couple of small-scale industries such as a removal company. In the northern part, there is also a long and busy commercial street interspersed with the long-established Tooheys brewery, hotels and bars. This is John Street.

The trend of business is upwards, judging by the rate at which new commercial activities are springing up. In the last three months, three additional Korean restaurants have been added. This is conspicuous on Joseph Street, and also in other places. Apart from being a visible business, real-estate agencies are springing up in in the neighbourhood, We counted three new ones in the last year, all located in the commercial precinct of Joseph Street. One of these is an "add on" to a hitherto small jewellery and grocery shop, and the others are new agencies. We do not have accurate data on their profitability because this information is not readily available. However, we know that Lidcombe is a middle class neighbourhood, no longer a working-class suburb like it used to be, as can be seen from Table 5.

Although our interactions with residents over the last two years that we have lived in the neighbourhood show that much of the working population lives in Lidcombe, not all workers live in this migrant neighbourhood. The key point is that even areas in the neighbourhood closest to the cemetery site now enjoy substantial economic vibrancy. The funeral and burial industry remains active. There is an industry for engraving and making cemetery monuments that employs local stonemasons. Apart from the one pictured (Figure 9), another is operated by the trust that manages the cemetery, and there is at least one more that is privately owned.

The Guardian Funeral Home is also active in planning and preparing funerals. This death-related industry actively advertises its activities, including in the Auburn Review, a municipal newspaper, and we also visited some of these businesses to confirm that they are active. However, the local economy is now more diversified.

The interpretation of these income classes has changed over the years, and so it is important to understand Table 6 in conjunction with Figure 7. Looking at them together shows the palpable economic prosperity in the neighbourhood and conspicuous decline in deprivation, whereas incomes seem to be uniformly distributed. These migrants remit money and send gifts back to relatives in their countries and invest in their

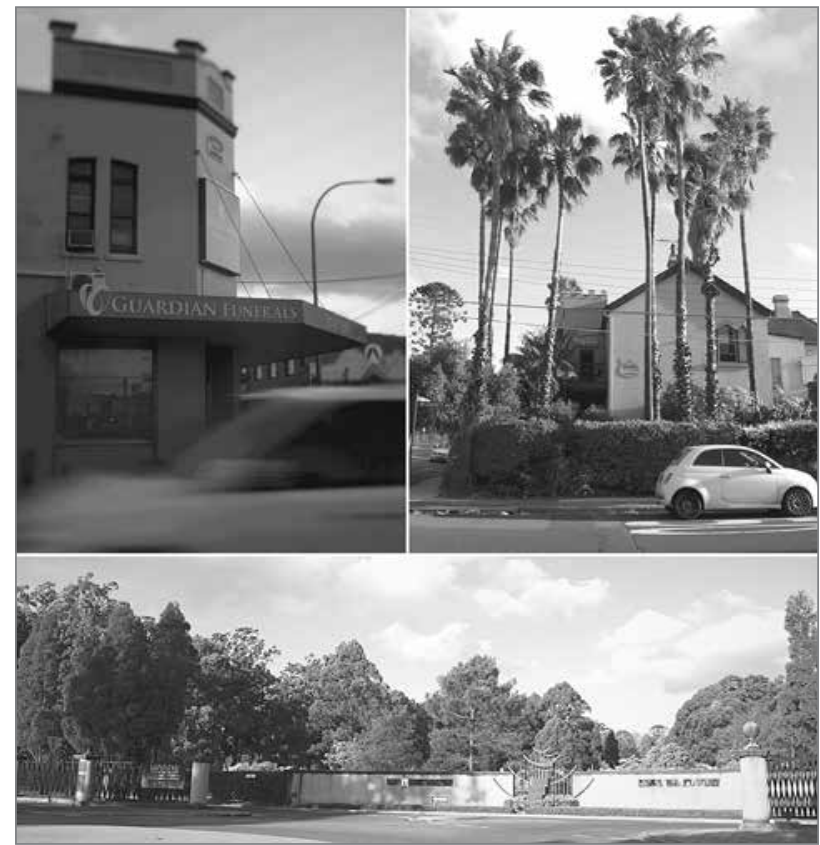

Figure 9: The funeral industry (photo: Hae Seong Jang).

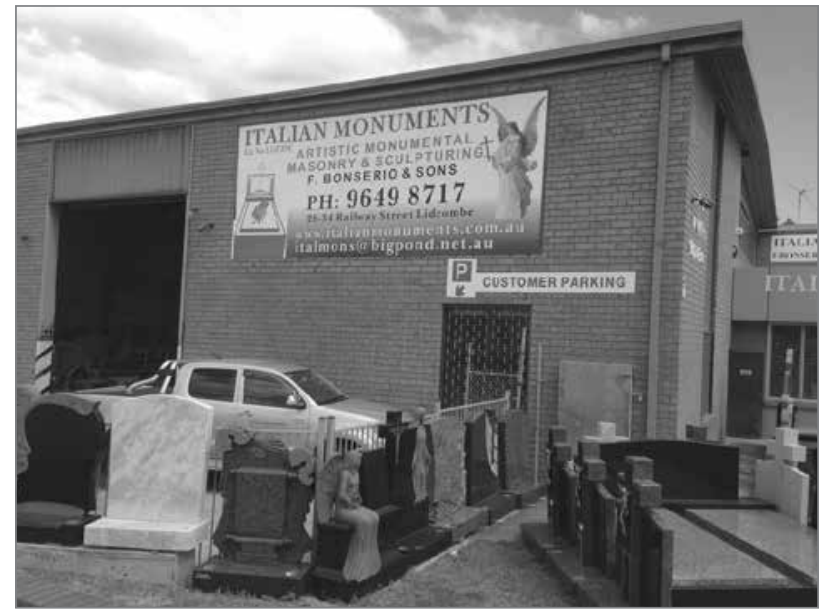

Figure 10: Gravestone and monument business in Lidcombe (photo: Franklin Obeng-Odoom).

countries of origin. It would be interesting to study whether there are any differences between this process and how Africans in Sydney generally send remittances to Africa (ObengOdoom, 2010).

\section{Conclusion}

To repeat the question posed at the beginning of this paper: how do migrants shape their local spaces and contribute to the host economy and society? Although the dominant view holds that the migrant footprint is emphatically negative, our case study suggests that the idea of a "migration effect" or "effects of migration" may be rather simplistic. The migration question 
is an empirical issue. Strongly associated with death and the dead, Lidcombe, a major migrant neighbourhood in Australia, is bustling with economic activity and renewal. Not only has the southern part, formerly mainly a settlement of the dead, been revamped with lively migrants actively working within and outside the local economy, the northern part has also continued to be vibrant and well settled. Life here has not only impacted Australia, the host country, positively through an expansion in its economic activities via multiple channels such as building, banking and billing, but also through variety in its social and moral economies. Simultaneously, the migrants do not seem to be exerting untold and undeserving demands on the Australian public. As contributors to Australia's common wealth, now active workers, the migrants will be entitled to their own share of the national prosperity, especially when there is no proof that they consume public resources to maintain peace and safety because the crime rate has fallen drastically over the years (Auburn City Council, 2013a). Not only have the migrants brought life to Australia, but they have also sent life to their relatives overseas. Remittances and tourism contribute to improving the social conditions of foreign countries just as foreign labour helps the host country, in the case of Lidcombe, to transform a dead city. The funeral industry exists, of course, but Lidcombe's local economy is more diversified today and looks poised to achieve further socioeconomic progress.

These findings significantly extend the existing literature on migrants, which assumes that they are in the diaspora but the "attachment to their homeland" suggests that they do not invest in their host countries (Min \& Park, 2014). In the case of Lidcombe, there is attachment to "home" in the sense of bringing "home culture" to Australia (e.g., eating out on a scale never before seen in the area), but the migrants have also transformed an old and dying township. Far from being just one ethnic enclave in the neighbourhood as other research shows happens (Kim, 2014), or one regional group of migrants investing in the investment property market as Franklin Obeng-Odoom's (2012b) earlier study of African migrants in Sydney shows, the neighbourhood is populated and transformed by migrants from different races, ethnicities and regions. In this sense, the study also extends the literature on the migrant transformation of neighbourhoods, which has previously concentrated on refugees and individual nationalities or ethnic enclaves (e.g., Stilwell, 2003). White Australians have moved out, but they have hardly been "pushed out" to occupy less ideal places. Thus, unlike the situation when the White population in Australia pushed out Black and Aboriginal groups in Australia to live in worse and isolated places (Jang, 2015), the White population that used to be in Lidcombe has moved to "better places" and economically benefitted from its departure. In turn, the story of Lidcombe is not merely a case of displacing the White population or simply a story about individual migrants becoming successful, as some research suggests (Saunders, 2012).

There are important problems such as increasing housing costs, a reduction in essential services, lack of mixing and possible radioactivity. Admittedly, these problems are generally symptomatic of migration in Australia. Moreover, the lack of cohesion leads to opportunities for policy intervention, linked with opportunities to foster greater mixing. Greater awareness through research disseminated in the community newspaper, the Auburn Review, together with multiple communication through written, visual and audio means can all be used to inform and sensitise people. A study of migrants in the United States by Jerry Park (2013) also shows that religious groupings are often vectors of insularity and ethnicity, but they can also be avenues for change, perhaps even the avante garde in the process of integration if they set out to make changes to their own organisation, which, in turn, might provide the grounds for example, for interracial marriage, another possible process of integration. The council provided free or subsidised multicultural English courses interspersed with topics about various cultures and race. Real-estate pricing and prices that are often pushed up through bidding are particularly worrying because they may result in bubbles and hence exacerbate affordability problems in the local economy. Ways to check the apparent mismatch between demand and supply and hence the need to resort to competitive bidding include implementing a Georgist land taxation programme to "cool down" the urge and motivation to speculate in a booming local economy. In addition, social housing packages can be implemented to expand the supply side of the housing market without pushing up rents. Starting such reforms for housing for migrants will itself be controversial, but the city authorities can promote it if they choose to, especially now when the council has a strong migrant base. For the same reason, greater mobilisation can be made to oppose plans to turn Lidcombe into a radioactive storage site. However, the analysis of the precise nature of the politics of change and the political economy of how different interest groups can resist change or be harnessed to support change will have to wait for another time.

For now, it will suffice to emphasise that migrants have brought life to Australia's dead city, life to themselves and life to their relatives overseas, without placing undeserved pressures on Australias finances. Just as the migration pattern (group migration) and the processes of change and continuity in Lidcombe have structural and historical underpinnings and dynamics, the story of Lidcombe contrasts with the assumption of individual migration that belies much thinking in economics, 
and Australian migration policy (i.e., policies on granting visas to such migrants) ought to accordingly reflect the "historicalstructural paradigm" of migration rather than the less nuanced neoclassical "economics of migration". Because migrants have succeeded in heading this major transformation in Lidcombe, there is a strong basis to support incoming migrants without policymakers and others chanting "over my dead body".

Franklin Obeng-Odoom

University of Technology Sydney, Australia, School of Built Environ-

ment, Australia

E-mail: Franklin.Obeng-Odoom@uts.edu.au

\section{Hae Seong Jang}

The University of Sydney (formerly) and currently affiliated with Yonsei University, Centre for Australian Studies, South Korea E-mail: hjan2486@uni.sydney.edu.au

\section{Acknowledgements}

We are grateful to David and Nola Basford, long-term and highly informed residents of Lidcombe, for sharing their detailed knowledge of and archival material on Lidcombe with us. Many thanks to real-estate agents and others (including railway staff, workers in religious organisations, shop owners/operators/workers and library staff), who offered their thoughts on the transformation in Lidcombe with us. Thanks also to Frank Stilwell, Australia's leading urban political economist, for helpful discussion on the broader context of urban development in Australia during the early stages of formulating this study. Both the external feedback solicited by Urbani izziv and the assistance of the journal's editor, Boštjan Kerbler, have been very extremely useful in improving the paper. None of these people are responsible for any aspects of our analysis, for which we take full responsibility.

\section{Notes}

[1] Data from Google Scholar search (keywords used: Frank Stilwell, Afghans) on 11 Jan. 2014.

${ }^{[2]}$ Newspapers also said there are no rooks, but crows. However, because both crow or caw, rook is acceptable (Hedges, 1992: 234).

\section{References}

Abreu, A. (2012) The new economics of neoclassicals bearing gifts. Forum for Social Economics, 41(1), pp. 46-67. DOI: $10.1007 / s 12143-010-9077-2$

Acharya, A. K. \& Codina, M. R. B. (2012) Social segregation of indigenous migrants in Mexico: An overview from Monterrey. Urbani izziv, 23(1), pp. 140-149. DOI: 10.5379/urbani-izziv-en-2012-23-01-006

Adogame, A. \& Lawrence, A. (2014) (eds.) Africa in Scotland, Scotland in Africa: Historical legacies and contemporary hybridities. Leiden, Brill.

Ashton, P. (2008) Suburban Sydney. Sydney Journal, 1(3), pp. 36-50.

Auburn City Council (2012) Economic profile: Business counts (staff) - Auburn City. Available at: http://www.economicprofile.com.au (accessed 5 Jan. 2014).
Auburn City Council (2013a) Auburn Crime Prevention Plan, 2013-2016. Auburn.

Auburn City Council (2013b) Community profile. Available at: http://profile.id.com.au/auburn (accessed 12 Sep. 2015).

Auburn City Council (2015a) Community profile, Auburn City: Birthplace - Auburn City. Available at: http://profile.id.com.au/auburn/birthplace (accessed 8 Oct. 2015).

Auburn City Council (2015b) Community profile, Auburn City: Populations, dwellings, and ethnicity - Auburn City. Available at: http://profile.id.com.au/auburn/population (accessed 8 Oct. 2015).

Auburn City Council (2015c) Community profile, Auburn City: Employment status - Auburn City. Available at: http://profile.id.com.au/ auburn/employment-status (accessed 8 Oct. 2015).

Auburn City Council (2015d) Community profile, Auburn City: Occupation of employment - Auburn City. Available at: http://profile.id.com. au/auburn/occupations (accessed 8 Oct. 2015).

Auburn City Council (2015e) Community profile, Auburn City: Household income quartiles - Auburn City. Available at: http://profile.id.com. au/auburn/household-income-quartiles (accessed 8 Oct. 2015).

Auburn City Council (2015f) Community profile, Auburn City: Household income quartiles - Auburn City. Available at: http://profile.id.com. au (accessed 8 Oct. 2015).

Auburn Review (1988) Let Lidcombe live again! Auburn Review, 20 Jul. 1988

Auburn Review (2008) Migrant concern. Auburn Review, 29 Apr. 2008.

Auburn Review (2014) Hunt on for local work. Auburn Review, 7 Oct. 2014.

Broomhill, R. (2008) Australian economic booms in historical perspective. Journal of Australian Political Economy, 61(June), pp. 12-29.

Burnley, I. (2006) Sydney's changing peoples: Local expressions of diversity and difference. In: Freestone, R., Randolf, B. \& Butler-Bowdon, C., (eds.) Talking about Sydney: Population, community and culture in contemporary Sydney, pp. 37-50. Sydney, UNSW Press Ltd and Historic Houses Trust.

Castles, S. (2008) International migration at the beginning of the twenty-first century: Global trends and issues. International Social Science Journal, 52(165), pp. 269-281. DOI: 10.1111/1468-2451.00258

Čolić-Peisker, V. (2004) Australian Croatians at the beginning of the twenty-first century: A changing profile of the community and its public representation. Croatian Studies Review, 3-4(1), pp. 1-26.

Collins, J. (2008) Globalisation, immigration and the second long postwar boom in Australia. Journal of Australian Political Economy, 61(June), pp. 244-266.

Collins, J. (2013) Rethinking Australian immigration and immigrant settlement policy. Journal of Intercultural Studies, 34(2), pp. 160-177. DOI: 10.1080/07256868.2013.781981

Collins, J., Gibson, K., Alcorso, C., Castels, S., \& Tait, D. (1995) A shop full of dreams: Ethnic small business in Australia. Sydney, Pluto Press.

Davidson, K. \& Gleeson, B. (2013) The urban revolution that isn't: The political economy of the "New Urbanology". Journal of Australian Political Economy, 72(summer), pp. 52-79.

Department of Infrastructure and Transport (2013) State of Australian Cities Report 2013. Canberra, Major Cities Unit, Government of Department of Infrastructure and Transport Canberra.

Division of Local Government, Department of Premier and Cabinet (2013) Local Council Boundaries Sydney Outer (SO). Sydney, New 
South Wales Government. Available at: http://www.dlg.nsw.gov.au (accessed 4 Jan. 2013).

Emerson, A. (2001) Historical dictionary of Sydney. Lanham, MD, Scarecrow Press, Inc.

Glaeser, E. (2012) Triumph of the city. London, Pan Books.

Gordon, L. (2008) Berala. Sydney Journal, 1(3), pp. 110-112.

Gunter, A. (2014) Renting shacks: Landlords and tenants in the informal housing sector in Johannesburg South Africa. Urbani izziv, 25(supplement), pp. 96-107.

DOI: 10.5379/urbani-izziv-en-2014-25-supplement-007

Han, J. J. \& Han, G. S. (2010) The Koreans in Sydney. Sydney Journal, 2(2), pp. 25-35.

Handmer, J. W. (1995) Managing vulnerability in Sydney: Planning or providence, GeoJournal, 37(3), pp. 355-368. DOI: 10.1007/BF00814017

Hedges, S. L. (1992) Liberty plains: A history of Auburn, NSW. Sydney, George Lewis Group.

Hugo, G. J. (2008) In and out of Australia: Rethinking Indian and Chinese skilled migration to Australia. Asian Population Studies, 3(4), pp. 267-291. DOI: 10.1080/17441730802496508

Jang, H. S. (2015) Social identities of young indigenous people in contemporary Australia: Neo-colonial north, Yarrabah. New York, Springer. DOI: 10.1007/978-3-319-15569-2

Johnson, J. (2009) Croydon. Sydney Journal, 2(1), pp. 92-97.

Kass, T. (2008) Lidcombe. Dictionary of Sydney. Available at: http://dictionaryofsydney.org/entry/lidcombe (accessed 14 Sept. 2015).

Kim, H. H.-S. (2014) Immigrant network structure and perceived social capital: A study of the Korean ethnic enclave in Uzbekistan. Development and Society, 43(2), pp. 351-379.

Kotze, N. (2013) A community in trouble? The impact of gentrification on the Bo-Kaap, Cape Town. Urbani izziv, 24(2), pp. 124-132. DOI: 10.5379/urbani-izziv-en-2013-24-02-004

Lalich, W. F. (2004) The development of Croatian communal places in Sydney. Croatian Studies Review, 3-4(1), pp. 95-124.

Marais, L., Ntema, J., Cloete, J. \& Venter, A. (2014) From informality to formality to informality: Extralegal land transfers in an upgraded informal settlement of South Africa. Urbani izziv, 24(2), pp. 46-54.

DOI: 10.5379/urbani-izziv-en-2014-25-supplement-011

Markaki, Y. \& Longhi, S. (2013) What determines attitudes to immigration in European countries? An analysis at the regional level. Migration Studies, 1(3), pp. 311-337. DOI: 10.1093/migration/mnt015

McGrath-Champ, S., Rosewarne, S. \& Rittau, Y. (2011) From one skil shortage to the next: The Australian construction industry and geographies of a global labour market. Journal of Industrial Relations, 53(4), pp. 467-485. DOI: 10.1177/0022185611412897

Min, P. G. (2014) Twice-migrant Chinese and Indians in the United States: Their origins and attachment to their original homeland. Development and Society, 43(2), pp. 381-401.

Mitchell, J. (2008) John Joseph Therry - His Lidcombe property. Australian Railway History, September, pp. 308-310.

Molho, I. (2013) Theories of migration: A review. Scottish Journal of Political Economy, 60(5), pp. 526-556. DOI: 10.1111/sjpe.12022

Monare, P. T., Kotze, N. \& McKay, T. M. (2014) A second wave of gentrification: The case of Parkhurst, Johannesburg, South Africa. Urbani izziv, 25(supplement), pp. S108-S121.

DOI: 10.5379/urbani-izziv-en-2014-25-supplement-008

Mourad, H. (2009) The development and land use impacts of local mosques. Honours thesis. Sydney, UNSW, Faculty of the Built Environment.
Moustafine, M. (2011) Russians. Sydney Journal, 3(2), pp. 55-64.

Obeng-Odoom, F. (2010) Urban real estate in Ghana: A study of housing-related remittances from Australia. Housing Studies, 25(3), pp. 357-373. DOI: 10.1080/02673031003711568

Obeng-Odoom, F. (2012a) Political economic origins of SekondiTakoradi, West Africa's new oil city. Urbani izziv, 23(2), pp. 121-130. DOI: 10.5379/urbani-izziv-en-2012-23-02-005

Obeng-Odoom, F. (2012b) The Ghana House Trust: An innovation by migrants? Global Built Environment Review, 8(1), pp. 37-44

Obeng-Odoom, F. (2013) Review of Arrival city: How the largest migration in history is reshaping our world. African Review of Economics and Finance, 5(1), pp. 76-78.

Obeng-Odoom, F. (2014) Oiling the urban economy: Land, labour, capital, and the state in Sekondi-Takoradi. London, Routledge.

Opoko, A. P., Ibem, E. O. \& Adeyemi, E. A. (2015) Housing aspiration in an informal urban settlement: A case study. Urbani izziv, 26(2), pp. 117-131. DOI: 10.5379/urbani-izziv-en-2015-26-02-003

Ozkul, D. \& Obeng-Odoom, F. (2013) Temporary migration in Africa: Views from the global south. African Review of Economics and Finance, 5(1), pp. 2-8

Park, J. Z. (2013) Ethnic insularity among 1.5- and second-generation Korean-American Christians. Development and Society, 42(1), pp. 113136. DOI: $10.2139 /$ ssrn. 2736054

Pickering, J. (2001) Globalisation: A threat to Australian culture? Journal of Australian Political Economy, 48(December), pp. 46-59.

Pollen, F. (1988) The book of Sydney suburbs. Auckland, Angus \& Robertson Publishers.

Portes, A. \& Yiu, J. (2013) Entrepreneurship, transnationalism, and development. Migration Studies, 3(1), pp. 75-95. DOI: 10.1093/migration/ mns036

Randolph, B., Holloway, D. \& Ruming K. (2005) Social outcomes of residential development, Sydney Olympic Park Stage 1: Local area analysis. Sydney, UNSW, City Futures Research Centre Publication.

Riley, R. \& Weale, M. (2006) Commentary: Immigration and its effects. National Institute Economic Review, 198(October), pp. 4-9. DOI: $10.1177 / 0027950106074029$

Saunders, D. (2012) Arrival city: How the largest migration in history is reshaping our world. New York, Vintage Books.

Serra, P. (2012) Global businesses "from below": Ethnic entrepreneurs in metropolitan areas. Urbani izziv 23(supplement 2), pp. S97-S106. DOI: 10.5379/urbani-izziv-en-2012-23-supplement-2-008

Stafford, T. (1991) Living in Liddy. Sydney, Ettalong Beach.

Stilwell, F. (1998) Globalization and cities: An Australian perspective. Review of Radical Political Economics, 30(4), pp. 139-167. DOI: $10.1177 / 048661349803000407$

Stilwell, F. (2003) Refugees in a region: Afghans in Young, NSW. Urban Policy and Research, 21(3), pp. 235-248. DOI: $10.1080 / 0811114032000113635$

Stilwell, F. J. B. (1979) Australian urban and regional development in the late 1970s: An overview. International Journal of Urban and Regional Research, 3(1-4), pp. 527-541. DOI: 10.1111/j.1468-2427.1979.tb00805.x

Šutalo, I. (2004) Croatians in Australia: Pioneers, settlers and their descendants. Kent Town SA, Wakefield Press.

Tsenkova, S. (2014) The housing policy nexus and people's responses to housing challenges in post-communist cities. Urbani izziv, 24(2), pp. 90-106. DOI: 10.5379/urban-izziv-en-2014-25-02-002 